\title{
Changing The Landscape Of The Retail Industry In The United States And Wal-Mart Phenomenon: A Brief Review
}

Sam Mirmirani, (Email: smirmira@bryant.edu), Bryant University

\begin{abstract}
This paper provides a quick review of the significant changes that have occurred in the retail industry in the United States. Of particular concern, are the more recent developments that occurred due to technological advances, i.e. E-commerce, and rapid growth in Wal-Mart's operations. It is noted that the industry has transitioned from a more competitive environment to an oligopolistic structure in which a few large firms dominate their respective market. The role of WalMart is evaluated and its impact on the economy, in general, and in the retail industry, in particular, is elaborated upon.
\end{abstract}

\section{INTRODUCTION}

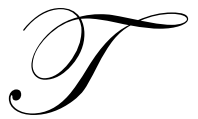

he retail industry in the United States has undoubtedly evolved over time. While shopping at brick and mortars and regional malls were preferred as the preference in the early 1980's, changing consumer needs and the decline of major department stores and retail chains have created a demand for online retail and new types of shopping centers. The changes in retailing result from many factors, not the least important of which is the economy. The increasing number of women employed outside of the home has greatly reduced families' available shopping time, thus resulting in the need for greater accessibility. Recent nationwide recession has resulted in decreased sales in the more upscale department stores as consumers once again realize the benefits of a traditional shopping experience. These factors have contributed to the latest in shopping center proposals emphasizing convenience and pricing while allowing shoppers direct access to goods. At the same time, unprecedented growth in E-commerce signifies the new trend and culture in the retailing industry in the United States.

The trend in traditional, brick and mortar, convenience shopping is being complemented by a retail industry shift towards the development of both super regional and power centers. A super regional center provides variety in general merchandise, grocery, apparel, furniture, and home furnishings, as well as a variety of services and recreational facilities. A power center is an alternative to both the smaller, more limited community shopping center and the larger, oversized regional mall. It is relatively new to the market, and although only a variation of existing centers, it offers something that the others types do not offer, it is simply a development center concept. For many retailers, the knowledge that, $75 \%$ of the time, people go to a mall for a particular store, leads them to believe that individual stores could and should be removed from a mall and created as stand-alone retail satellites forming a power center.

The success of power centers is not merely a function of their large size and low overhead costs. Power centers provide an environment previously not available in traditional malls or shopping strip centers - that is the shopping convenience of a strip center with the regional draw of an enclosed mall. In the power center concept, individuals can drive up to the front door of their favorite store. In addition to convenience, power centers offer increased specialization. Anchor retailers offer a wider selection of a particular category of merchandise and dominate their categories through mass merchandising. 


\section{E-COMMERCE AND ONLINE SHOPPING}

The emergence of electronic commerce gave the retailing industry in the United States the needed boost following the general slowdown of the economy in the late 1990s (Delano, 2000; Marsan and Mears, 2001). With Internet technology accessible to most, E-commerce became more the norm rather than the exception. This pattern forced traditional businesses such as Sears Roebuck \& Co. and Barnes and Nobles to re-strategize their business operations. The presence of E-commerce in the retail industry and its potentially significant impact on the US economy is elaborated in Coy (1998).

Technological revolution in retailing has become a global phenomenon and no longer specific to the United States. The Organization for Economic Cooperation and Development (OECD) realized the "profound" economic impact electronic commerce had on its members (OECD, 2000). In 2000, domestic online sales reached $\$ 12$ billion (Fischer, 2001), a 66\% growth from previous year. Four years later, such sales exceeded $\$ 145$ billion or $7 \%$ of the entire US retail sales (Mullaney and Hof, 2004). According to Barbaro (2005) the online sales (including auction sites) in November and December of 2005 reached \$30.1 billion, a 30\% rise from 2004.

\section{DEMISE OF SMALL BUSINESS}

When asked about the ramifications of the rise of superstores upon small independent bookstores, a store owner observed, "... this isn't the first time there's been such an air of chain-based uncertainty in the industry...During the early to mid-eighties, with the rise of mall stores... it was predicted that chain stores would take over $75 \%$ of national book sales, but we weathered that storm." (Faatz, 1993, p. 401)

Small businesses have been faced with "super store" competition in the past and have managed to not only survive, but also in some cases actually thrive. One method by which small businesses have been able to succeed is by targeting niche markets and providing services the larger stores cannot provide. In a sense, when faced with such overwhelming competition, small businesses must look to their strengthens be willing to change the manner by which they conduct business.

A case in point has been the emergence of super office stores. For many years, the independent office supply store only served big businesses and competed through service as well as price. Knowing the specific needs of a customer and delivering supplies on time still remains a high priority for many businesses. Price is only one item that a business considers when making a decision regarding where to shop. The introduction of the super office store has affected today's consumers by offering them a broader choice of suppliers for their office needs than ever before. The key to selecting suppliers is to determine the mix of products, services, and pricing that will allow office managers and buyers to have their needs met most efficiently and cost effectively. This includes the need for small businesses to continue to service a market they have done in the past. Similar examples can be found in small hardware stores confronted with sweeping pressure from Home Depot and Lowes super hardware centers.

\section{WAL-MART PHENOMENON}

The most widely publicized example of a mass merchandiser's impact upon small business is the case of Wal-Mart. The phenomenon began with Sam Walton, who opened the Five \& Dime store in 1950. By 2005, the number of Wal-Mart store exceeded 1,900 (Yerak, 2005). When the decision to locate a Wal-Mart in the small town of Greenfield, MA was announced, citizens formed a group to block its construction, citing the adverse impact to local downtown merchants. Sensitivities on both sides were high and a decision was made to put this issue to a town vote. The results of the vote were extremely close, decided by only 9 votes out of a total of 10,400 cast. The losing citizens bemoaned the loss by saying, "the town could use the jobs," (Sophfronia, 1993, p. 57).

Professor Kenneth Stone of Iowa University, an authority on the impact of Wal-Mart location decisions upon small towns and businesses in Iowa has concluded, "Recent studies also weaken the argument that the large retailers hurt the economy of the communities while the number of small retailers did decline, other business was attracted to the area." Thus the nature of a market economy whereby there will be winners and losers (Sophfronia, 1993, p. 57). 
Professor Stone elaborates on his conclusion in a study entitled, "Competing with the Mass Merchandisers" (Stone, 1991, pp. 33-36). "Mass merchandisers, particularly the discount general merchandisers such as K Mart and Wal-Mart, are growing at a rapid rate and have captured market share from smaller firms. It is possible to survive in such an environment, but substantial changes in operations are usually required." Citing the "pull-factors" that a WalMart has to attract business into an area the study went on to conclude, "The major plus for most businesses was that in virtually all cases, total sales in the town increased at a rate greater than average for the state." But there were negatives also, "... when a well-known national chain like Wal-Mart opens a large store in a relatively small town, it invariably will capture a substantial slice of the retail pie. The end result is that other merchants in the area will have to make do with smaller slices of the retail pie, or get out of business."

One interesting result from the entry of a Wal-Mart into an area is that it forced smaller stores to improve their offerings as well as their appearance. Also, it caused some smaller suppliers to form "buyers groups" to gain economies of scale and take advantage of quantity discounts.

Professor Stone's conclusion is, "The best strategy for merchants in these towns is to get back to the basics of running a good business and focus on making service a strong competitive advantage...It is possible to exist in the face of competition from discount mass merchandisers. There are many documented cases of merchants surviving and in some cases thriving when operating against such formidable competition. However, most of these merchants did not continue business as usual. They made many of the changes suggested above, including major changes in merchandise mix."

Currently, Wal-Mart is the world's largest retailer. Benefiting from economies of scale and scope, Wal-Mart has succeeded in consolidating its market power by forcing the majority of smaller business and some of the larger retail superstores (K-Mart) out of the market.

The global presence of Wal-Mart is indicative of its market strategy and long-term dominance. Worldwide, Wal-Mart employs near 1.5 million people and operates about 5,000 stores; therefore, its economic benefits and costs are noticed and carefully monitored internationally. Currently, the Wal-Mart phenomenon remains controversial, at best. It is referred to as "economic disease" (Freeman and Ticknor, 2003) and its massive growth is suggested to have a destructive impact on cites and town across the US (Freeman, November 21, 2003). Wal-Mart's anti union strategies, cutthroat and predatory pricing, and taking advantage of sweatshops in underdeveloped countries, are among a few criticisms among the public. Considering its immense buying power, Wal-Mart squeezed bottom-line profit out of domestic manufactures and suppliers. At the same time, an over-valued dollar enabled Wal-Mart to exploit cheap labor abroad causing the further demise of domestic textile (Carolina mills and Lovable Garments) and apparel suppliers (Sears, J.C. Penny, and Target). Their food and grocery operations had similar impacts on Safeway and Kroger. See Freeman (November 28, 2003).

Sensing a potential expansion of the online market, Wal-Mart exerted its role by becoming the third most popular site, just trailing behind Amazon and eBay (Barbaro, 2005). Through Walmart.com, the giant is adding even more diversity in merchandizing (Fleming 2005), with an emphasis on higher end products (e.g. leather furniture from Italy) and "trend forward" items. According to Thau (2005), in late 2005, Walmart.com offers over one million products and serves over 500 million shoppers. Its growth rate is more than double the online industry average.

There are, however, some studies that support the Wal-Mart phenomenon. When Wal-Mart is compared with GM and criticized for its worker abuse, minimal health care insurance and other benefits for its already low paid employees, Maich (2005) asserts that such allegations are exaggerated and politically motivated. Focusing on its staggering sales and consumer savings, Maich (2005) points out that Wal-Mart follows the industry norms and rising health care costs has threatened the stability of GM. In another study, Semmens (2005) concentrates on the Wal-Mart benefits for the economy and concludes its trade with less-developed countries has stimulated the third world economies, and it should be "a model" for how capitalism should work in a global environment. With the logo of Wal-Mart, the home of "always low prices," a study by Global Insight Research (www.globalinsight.com/walmart) and Troy (2005) points out that in paying competitive wages, creating large number of new jobs, the company in 2004 , benefited its consumers. Their savings reached $\$ 263$ billion, or an average of $\$ 895$ per person. As a summery, 
the negative and positive impacts of Wal-Mart on various constituencies are presented in schematic model in figure 1.

Figure 1- SCHEMATIC OF WAL-MART IMPACTS

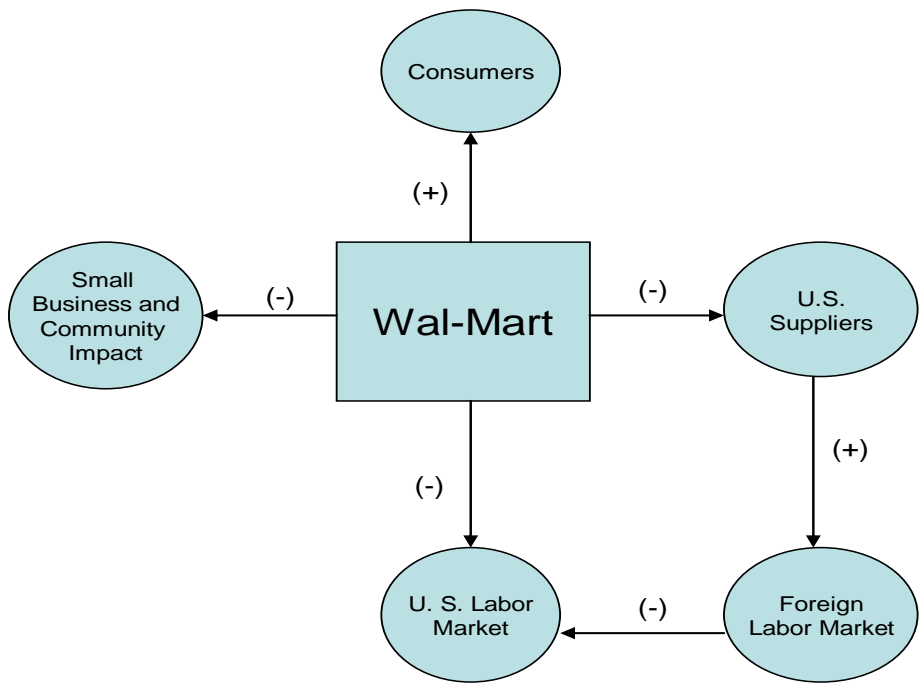

Recently, Wal-Mart's appetite for market dominance has extended beyond merchandizing. Perhaps an even more controversial business issue is Wal-Mart's aspiration to expand their commerce into banking and finance related activities. This has caused much "anxiety" in the financial service industry as pointed out by Graver (2005). WalMart's money-service activities involve millions of transaction per week such as check cashing, money transfers, and money orders. Many companies are not renewing their contracts for operating ATMs in Wal-Mart and Sam's Club stores, and Wal-Mart is replacing these ATMs with machines called MCX (Money Center Express), which are owned by Wal-Mart. As one can see, Wal-Mart has already taken initiatives to pave the way for becoming the community banker of the future. Seeking a banking charter, Wal-Mart's intent is to save money for the company in the wholesale card-payment process. More specifically, such savings are the result of eliminating acquiring fees relevant to ATMs. Another concern over this move is the possibility of Wal-Mart leveraging its banking power over its supplier network (Brietkopf, 2005). Some argue that Wal-Mart's move into banking should be stopped on the grounds of separation of banking and commerce. However, making a reference to the Gramm-Leach-Bliley Act, Wal-Mart's application to establish an Industrial Loan Corporation (ILC), which is pending approval of the FDIC, Wallison (2006) suggests that such application can not be opposed. In addition, the Independent Community Bankers of America, citing this move 
as unfair competition, is more concerned abut the survival of the small community banks and the constituency that they (Fine, 2006).

\section{SUMMARY AND CONCLUSION}

The past 25 years reveals a major change in the direction and structure of retail business in the United States. The era of community-focused, small businesses gave way to the nationally, and in certain cases internationally, operated mega retailers. With the ability to accumulate and maintain large capital, these giant businesses have been able to diversify their merchandizing operations to a wide range of tangible and intangible goods. The location theories that have been the guide for business decisions in the past, are a "thing in the past" and no longer applicable for the most part, attributable to the growth of E-commerce.

A closer look at the retail industry suggests shrinking market competition and growth in super store operations are perhaps the most fundamental changes in the industry. Small neighborhood bookstores and music stores were forced out of the market place by Barnes and Noble and Borders just as local hardware stores were replaced by Home Depot and Lowes. Other related services such as plumbing, electrical, carpentry, cleaning and landscaping services that were once local neighborhood businesses have also felt the pressure from large national chains. In other words, a competitive industry has transitioned into an oligopolistic market.

The second fundamental development is advances in technology, which have brought a new dimension to retail in the United States, and inevitably to the world. Online retail advantages include lower capital investment, better and more efficient cash dynamics, unlimited shopping hours, customized shopping for consumers, easier global expansion, and p product and service diversification (Fischer, 2001). Because of these benefits and a fairly limited number of disadvantages, E-commerce has grown exponentially since mid-1980s. The major economic impact of this new way of "doing business" has already been realized by macroeconomic policy makers. The profound impacts on macroeconomic performance caught the attention of OECD and forced revisions in macro policy management (OECD 2000).

Perhaps, the third most notable, yet quite controversial, change involves the astronomical growth in WalMart's business. While economies of scale and scope is the primary business strategy of Wal-Mart to compete in and control the retail market thereby substantial savings for the buyers, Wal-Mart's negative impacts on local communities and labor market are evident. Yerak (2005) predicts Wal-Mart's retail trade will account for $12 \%$ of the entire industry by 2010. With this growth, it is concluded that giant retailer "will have a material influence on gross domestic product."

The attack on Wal-Mart's expansion has turned into a local and state political campaign strategy. These include, but are not limited to, the labor union-backed and community business-supported campaigns, which will undoubtedly occupy the national political agenda. In the past, pressures on political establishments have resulted in changing state and federal government policies; this may also be the case in the future, however, one fact remains clear in the retail industry. The role of Wal-Mart in the retailing business in the United States can be deemed as "creative destruction of capitalism."

\section{RFERENCES}

1. Barbaro, Michael, (2005), Internet Sales Show Big Gains Over Holidays, New Your Times, December 30, p. A-1.

2. Brietkopf, David, (2005), Wal-Mart's Financial Vision: In Payments: Spotlight on An ILC's Role, American Banker, October 5.

3. Coy, Peter, (1998), You Ain't Seen Nothin' Yet: The benefits to the economy of E-commerce are boundless, Business Week, No. 3583, June 22, pp. 130.

4. Delano, Daryl, (2000), U.S. Economy is Finally losing a Little Steam, Electronic Business, Vol.26, No. 8, August, pp. 21-23.

5. Faatz, Chris, (1993), The Independent Eye, The Nation, Vol. 257, No.11, Oct. 11, p. 401. 
6. Fine, Camden, (2006), Banking and Commerce All in One Bundle, Wall Street Journal, Online, January 11, pp A-1.

7. $\quad$ Fischer, Jeff, (2001), Clicks for Bricks, Newsweek, Vol. 137, No 7, February 12, pp. 66-68.

8. Fleming, John, (2005), WalMart.com Easy Access to More Wal-Mart, DSN Retailing Today, Second Quarter, pp 6.

9. Freeman, Richard, (2003), Wal-Mart Collapses U.S. Cities and Towns, Executive Intelligence Review November 21.

10. Freeman, Richard and Arthur Ticknor, (2003), Wal-Mart is Not a Business, It's an Economic Disease, Executive Intelligence Review, November 14, 2003.

11. Graver, Robert, (2005), Wal-Mart's Financial Vision: In Retail: Focus on Unbanked, Partnerships, Home Grown ATMs, American Banker, October 5.

12. Maich, Steve, (2005), Why Wal-Mart is Good, Maclean's Vol. 118, No. 30, July 25, pp. 26-34.

13. Marsan, Carolyn and Jennifer Mears, (2001), Economic Slowdown to Test Net Exec's Mettle, Network World, Vol. 18, No.2, January 8, pp.1-3.

14. Mullaney, Timothy and Robert Hof, (2004), E-Tailing Finally Hits Its Stride, Business Week, No. 3913, December 20, pp. 36-37.

15. OECD, (2000), E-commerce: Impacts and Policy Challenges, OECD Economic Outlook, No. 67, June, pp. 193-214.

16. Semmens, John, (2005), Wal-Mart is Good for the Economy, Freeman Irvington-on-Hudson, Vol.55, No. 8, October, pp. 8-11.

17. Sophfronia, Gregory, (1993), They're Up Against the WAL, Time, Vol. 143, No 18, Nov. 1, p. 57.

18. Stone, Kenneth, (1991), The Impact of Wal-Mart Stores on Other Businesses and Strategies for co-Existing, Working Paper, Iowa State University, Department of Economics, Small Business Forum, Spring, pp. 33-36.

19. Thau, Barbara, (2005), Wal-Mart Goes Upscale Online For the Holidays, HFN: The Weekly Newspaper for the Home Furnishings Network, Vol. 79, No. 49, December 12, pp. 1.

20. Troy, Mike, (2005), Advanced Economics, Chain Store Age, Vol. 81, No. 12, December, pp. 1.

21. Wallison, Peter, (2006), Wal-Mart's Application to Establish or Acquire an Industrial Loan Corporation Chartered by the State of Utah has Thrust the Hoary Issue of Separating Banking and Commerce Back into the News, American Banker, January 13.

22. Yerak, Becky, (2005), Walmart to Heavily Influence Economy by 2010, Analysts Predict, Knight Rider Tribune News Service, May 12, Washington, pp.1. 